\title{
Purist or Pragmatist? UK doctoral scientists' moral positions on the knowledge economy
}

\author{
Sally Hancock ${ }^{\mathrm{a}^{*}}$, Gwyneth Hughes ${ }^{\mathrm{b}}$ and Elaine Walsh ${ }^{\mathrm{a}}$ \\ ${ }^{a}$ Graduate School, Imperial College London, London, SW7 2AZ, UK; ${ }^{\mathrm{b}}$ Institute of Education, \\ London, WC1H OAL
}

\begin{abstract}
Doctoral scientists increasingly forge non-academic careers after completing the doctorate. Governments and industry in advanced economies welcome this trend, since it complements the 'knowledge economy' vision that has come to dominate higher education globally. Knowledge economy stakeholders consider doctoral scientists to constitute particularly high-value human capital; primed to contribute to economic growth via the creation and application of scientific knowledge. Little is known, however, about doctoral scientists' awareness of, and attitudes towards, the knowledge economy. This paper reports a study of UK doctoral scientists, which reveals they are aware of, but ideologically divided towards, the knowledge economy. The knowledge economy relates to their scientific motivations, values, and aspirations in complex ways. Four moral positions emerge, ranging from 'anti' to 'pro' knowledge economy. We discuss the characteristics of each moral position, concluding with the need for doctoral scientists to adopt better informed and more flexible professional outlooks.
\end{abstract}

Keywords: doctoral scientists, knowledge economy, contemporary science, moral position

\section{Introduction}

In both developing and advanced economies, it is widely accepted that future economic growth is dependent upon the creation, transfer and application of knowledge. This vision - referred to as the 'knowledge' or 'knowledge-based' economy (KBE) - and its implications for science, the university and wider society has attracted the attention of scholars for over half a century (for example: Malchup 1946; Bell 1973; Gibbons et al. 1994; Stehr 1994; Castells 1996; Nowotny, Scott and Gibbons 2002).

Universities are considered fundamental to the KBE, owing to their position as producers of both knowledge and highly-skilled human capital (Temple 2011, ix). International trends in higher education (HE) suggest that, increasingly, the characteristics of the KBE are realised. University mission statements aspire to the commercialisation of research, while knowledge transfer offices are commonplace. The growing involvement of private finance in both teaching and research is well documented (Marginson 1997; Slaughter and Leslie 1997; Slaughter and Rhodes 2004).

In the UK, doctoral students in science, technology, engineering and mathematics (STEM) are particularly feted by policy-makers and industry who promote the KBE. Although a recent House of Lords Select Committee inquiry noted the absence of 'reliable data on the supply of and demand for STEM graduates and postgraduates' $(2012,6)$, it is the longstanding view of the business community that 'STEM skills shortages are widespread' (Confederation of British Industry 2011, 7). Successive UK governments have prioritised the latter perspective and, convinced of the economic imperative for STEM skills, consistently promote growth in these subjects (HM Treasury and Department for Business Innovation and Skills 2011, 87-88).

The special interest in doctoral scientists is two-fold. Partly, it is a matter of discipline: STEM knowledge is deemed more economically valuable than humanities, arts and social science knowledge (HM Treasury 2002, 2004; Callender 2010, 1). Secondly, doctoral scientists are differentiated from other STEM graduates since they are thought to possess expert knowledge, as well as the creative aptitude for innovative and entrepreneurial activity (Walsh et al. 2011).

Looking beyond the policy-business consensus, the academic community appears conflicted towards the KBE. The matter of whether the KBE is a positive or negative development for the university is addressed extensively in the literature, with no obvious agreement (see, for example: Etzkowitz 1983; Gibbons et al. 1994; Marginson 1997; Slaughter \& Leslie 1997; Etzkowitz and

*Corresponding author. Email: sally.hancock@york.ac.uk 
Leydesdorff 2001; Fuller 2003; Slaughter and Rhodes 2004; Barnett 2011; Lauder et al. 2012; Collini 2012). However, despite their casting as indispensable future knowledge workers, doctoral scientists seldom contribute to these debates.

This paper shares the results of a two-year study of doctoral scientists based at a researchintensive UK university, exploring their awareness of, and attitudes toward, the KBE. We begin by examining the theoretical foundations of the KBE and its translation into UK higher education policy. We then review current literature on the STEM PhD and doctoral scientists. This is followed by a description of the study's method before presenting doctoral scientists' awareness of, and varied attitudes towards, the KBE. Finally, the implications of these findings are discussed.

\section{Context: the knowledge economy}

The KBE is a complex and multifaceted concept, which Peters $(2009,66)$ describes as 'in the making' still. It has developed from diverse theoretical influences, prominent among which are: economic theory (neoliberal economics, endogenous growth theory), political theory (neoliberalism, third-way socialism), theories of knowledge creation and management, and, postmodernism.

Despite its theoretical 'fuzziness' (Barnett in Temple 2011, 213), interpretations of the KBE - particularly in relation to higher education and science - tend to place emphasis upon its capitalist characteristics. Steve Fuller characterises the KBE as 'capitalism of the third-order' (Fuller 2003, 106). Fuller's reference to the 'third-order' is significant. In this latest stage of capitalism, the indicators of basic competition for profit (first-order) and expenditure as advantage (second-order), are replaced by a new overarching aim: the acquisition of the knowledge. Knowledge is the primary means of securing competitive advantage, market share and profit; thus, knowledge is transformed into an economic commodity (Fuller, 116).

This is not to say that knowledge easily lends itself to commodification. Regulation, for example, is problematic. Attempts to monopolise knowledge creation or prevent knowledge dissemination may inhibit profit-making and economic growth. Unlike most commodities, the value of knowledge does not diminish with prevalence. Theorists and advocates of the KBE have therefore tended to limit themselves to two main areas of interest: knowledge in and of itself, and, knowledge possessed by humans. From hereon, we will refer to these two aspects of the KBE as a) knowledge creation, application and dissemination, and b) human-capital.

Given this emphasis on both knowledge creation, application and dissemination, and developing human-capital, it is unsurprising that the university is regarded as 'the key motor of the KBE' (Temple 2011, 1). In what follows, we outline policies developed in the UK aimed at fostering this dual supply of knowledge and human capital; noting that these developments largely reflect the strategies of developed economies internationally.

\section{The knowledge economy in UK higher education policy}

Economic valorisations of higher education are not entirely new, dating back to the $1960 \mathrm{~s}$ in the UK (Wolf, 2004, 316). Nevertheless, the New Labour government's (1997-2010) commitment to developing the UK's KBE presented a step-change in message (Driver and Martell 1999, 2); from which the current coalition government (2010-) has not markedly altered course. We will now consider the key KBE policies designed and implemented under both administrations.

\section{a) Knowledge creation, application and dissemination}

The 1998 white paper Our Competitive Future set out New Labour's vision for the UK KBE. In its foreword, Prime Minister Tony Blair asserted that 'enterprise, flexibility and innovation' would drive the UK's future global economic competitiveness, noting especially the role of 'science...enterprise [and]...creative partnerships' (DTI 1998, 5). Such political commitment endured throughout the New Labour administration; encouraging increased university-industry collaboration (Lambert 2003), and acknowledging the state's financial responsibility for developing KBE infrastructure (Sainsbury 2007). The coalition government continues to prioritise the 
development of the UK's KBE; promoting university-industry collaborations (Dyson 2010), and overseeing the Research Excellence Framework, which emphasises the economic value of research in assessing quality. The assumption that higher education drives innovation, and that innovation in turn leads to economic growth, therefore finds firm, cross-partisan support across the British political system; as the early pages of the Browne review (2010) relate.

Higher education matters because it drives innovation and economic transformation. Higher education helps to produce economic growth, which in turn contributes to national prosperity.

(Browne 2010, 14)

\section{b) Developing highly-skilled human-capital}

Human capital is by no means a homogenous concept, but the definition privileged in KBE policies is indebted to the economist Gary Becker. For Becker (1993), human capital is the sum of an individual's knowledge and skills which, when increased, elevate individual productivity (and position) in the labour market. In KBEs, universities are the principal institution for nurturing human capital. Such thinking underpinned New Labour's ambition to see fifty per cent of all young adults participate in higher education (Labour Party 2001, 7); and, continued to yield influence one decade later, informing Browne's view of the value of individual participation in higher education.

Higher education matters because it transforms the lives of individuals. On graduating, graduates are more likely to be employed, more likely to enjoy higher wages and better job satisfaction, and more likely to find it easier to move from one job to the next.

(Browne 2010, 14)

The human capital argument underpinning KBE policies therefore appeals widely; it benefits both society (economic growth) and the individual (upwards social and economic mobility). However, as subsequent policies demonstrated, not all skills are considered equal in the KBE. Individuals with a STEM doctorate are prized above all for their specialist subject knowledge, analytical and research skills, and capacity to innovate (Council for Industry and Higher Education 2010, 5; Select Committee on Science and Technology 2012, 39-40).

\section{The knowledge economy and the UK STEM doctorate}

The prominence of the KBE in discourses of UK higher education prompted debate about the 'purpose' and 'fitness' of the PhD (Park 2005; 2007). Powell and Green suggest that public perceptions of the doctorate are increasingly influenced by the KBE vision, with taxpayers now expecting an economic 'repayment' for their contribution to doctoral training (Powell and Green 2007, 233).

The Roberts Review (2002) was commissioned to examine the supply of STEM knowledge and skills in light of the government's productivity and innovation strategy. The STEM doctorate received significant attention in the Review, and the concerns raised by Roberts led to a number of reforms. Notably, this meant that all STEM PhD students funded by Research Councils UK (RCUK) undertake two weeks of dedicated transferable skills training per academic year to enhance students' commercial awareness and entrepreneurial skills. A review in 2010 concluded that Roberts transferable skills courses had become an 'integral part' of the UK's postgraduate research programmes, and were vital for the development of the UK's KBE (Hodge 2010, 30). Similar debates over the 'fitness' of the STEM doctorate are seen internationally also, including in the USA (Nyquist 2002) and Australia (Gilbert 2004).

UK doctoral graduates from all academic disciplines increasingly embark upon careers outside of the academy (Vitae 2011, 2013). This trend is somewhat inevitable, since, both in the UK and internationally, doctoral graduates outnumber available academic positions (Science is Vital 2011, 5; Barnacle and Dall'Alba 2011; Sauermann and Roach 2012). The extent to which post- 
doctoral career trajectories reflect individual choice is relatively under-researched; however, recent studies of American and Canadian doctoral students suggest that personal circumstances, such as relationship status, caring responsibilities and ties to a particular locality, together with lifestyle considerations strongly influence post-graduation intentions (McAlpine and Emmioglu 2014; Mason, Goulden and Frasch 2009). Specifically, views of doctoral students' attitudes towards the $\mathrm{KBE}$, and how these might related to students' motivations and post-doctoral ambitions are absent from the literature.

\section{Method}

Data were collected from UK domiciled doctoral scientists at a research-intensive university, over 18 months. The participating institution specialises in STEM, and is committed both to the commercialisation of scientific research and informing evidence-based policy. For this reason, the researchers considered it a particularly pertinent context to explore the influence of KBE policies on doctoral scientists. Furthermore, two members of the research team were employed at the institution, facilitating access to the research population. The study received full ethical approval from the participating institution. Participation was voluntary, and students were briefed on the aims and intended outcomes of the study. Consent was therefore considered fully informed.

The study employed mixed qualitative and quantitative methods, consisting of focus groups, a survey, and interviews. Qualitative data were collected through focus groups and interviews, while the survey comprised mostly closed questions, and generated quantitative data. Triangulation of methods and data occurred at various points in the study. Preliminary analysis of the focus group data informed the design of the survey, and survey data informed the interview schedule.

All UK domiciled STEM doctoral students registered in 2010 were included in the research population. Non-UK students were excluded given the study's focus on UK KBE policies, and the political emphasis on developing human capital at home. Further, it was considered desirable to select participants who were likely to have entered higher education under the New Labour government, when KBE narratives rose to prominence; and, to some extent, limit other variables which likely shape attitudes towards undertaking a $\mathrm{PhD}$, such as differing national models of higher education and distinct systems of financing undergraduate and postgraduate study.

Three focus groups were held between February and March 2010, to strengthen the development of the survey. All individuals within the research population were invited to participate. In order to limit self-selection bias, the research team shared little detail about the discussion topics prior to the sessions. Eight doctoral scientists, drawn from a range of disciplines and stages of study, attended each focus group. The focus groups allowed the research team to ascertain students' initial thoughts on the relevance of the study (which were mostly positive), and ensure that survey content reflected students' concerns.

The survey ran online from July to August 2010. Survey content was informed by the review of academic and policy literature, and focus group data. The survey elicited students' views on: awareness of, and attitudes towards, the knowledge economy; awareness of UK higher education policy over the preceding decade; historic and contemporary purpose(s) of higher education and the doctorate; motivations for undertaking doctoral study; and, future aspirations. As stated, for the purpose of generating quantitative data, the survey comprised mostly closed questions, which also reduce completion time and participant error (Cohen et al. 2011: 382). The majority of closed questions included an 'other' option and accompanying text box for additional comment.

All individuals within the research population received an email invitation containing the survey URL. The research team sent reminders at the approximate mid-point of the survey run, since these are known to increase response rates (Dillman et al. 2009). The survey closed with a response rate of $15 \%(n=165$ [eligible and complete responses only]). While the academic literature is divided on the issue of an 'acceptable' response rate; it is acknowledged that responses to student surveys have fallen internationally over the last decade (Coates 2006; Sid Nair et al. 2008). Low response rates undermine confidence in the extent to which an achieved sample is 
likely to be similar to the research population. However, in this case the survey sample well reflected the research population in terms of key personal and academic variables, including age, gender, mode of study and subject area. The representativeness of the survey sample therefore assuaged any initial concerns over the response rate.

While a survey sample of this size is amenable to descriptive statistical analysis, it was considered limited for the purposes of conducting inferential statistical analysis (i.e. testing for a significant association between one or more variables) (Cohen et al.: 144). The research team thus concentrated on generating frequencies for each survey question, which enabled an impression of the range of views and values relating to main issues covered by the survey.

Preliminary analysis of the survey data informed the content of the interviews, which were conducted between May and June 2011. The interviews addressed salient themes arising from the survey data, and explored further the particular viewpoints of interviewees. Sixty-eight doctoral scientists ( $41 \%$ of the survey sample), volunteered to participate in the interviews. Twenty students, selected to represent the range of attitudes and individual and academic characteristics recorded in the survey, were interviewed ${ }^{1}$. Interviews followed a semi-structured approach and typically lasted one hour.

Interview data were recorded, transcribed, inductively coded and analysed following a grounded theory informed approach (Strauss and Corbin, 1998). As noted earlier, doctoral scientists' views on the KBE, and the manner in which KBE ideals and policies relate to students' motivations and aspirations, had been little explored prior to this study. This research sought to include doctoral scientists in a discussion of the KBE, but wished to avoid the application of a presupposed analytical framework, shaped by prominent themes in the academic and policy literature. Grounded theory thus offered a most appropriate analytical approach, since themes and codes are generated inductively from the dataset. The typology of student identities presented is grounded in both the survey and interview data.

\section{Results: doctoral scientists' awareness of, and attitudes toward, the knowledge economy} The survey data revealed that a large majority of doctoral scientists knew of the knowledge economy (89\%). Table 1, below, shows the proportions of survey respondents who had encountered the following anticipated characteristics of the knowledge economy through the course of their working lives as doctoral scientists.

\begin{tabular}{l|r}
\hline Characteristic of the knowledge economy & Survey respondents (\%) \\
Increased multidisciplinary research & 86 \\
Encouragement of doctoral scientists to: & 71 \\
a) be entrepreneurial & 67 \\
b) prioritise applied research over basic & 54 \\
c) commercialise their research (e.g. develop patents) & 63 \\
Increased funding for, and politicisation of, STEM & 51 \\
Increased university-industry collaboration & \\
\hline
\end{tabular}

Table 1. Characteristics of the knowledge economy encountered by doctoral scientists

\section{Four moral positions}

Following a process of inductively coding the interview data, four moral positions towards the KBE emerged. This initial model was checked against the survey data, enabling us to test its

\footnotetext{
${ }^{1}$ With regard to individual and academic characteristics, the following variables were considered: age; gender; previous university; previous work experience; subject area of PhD; year of study; mode of study; funding source.
} 
validity and identify patterns in terms of the personal and academic characteristics of students belonging to each moral position.

We refer to these positions as 'moral' since doctoral scientists' attitudes towards the KBE are inextricably tied to broader reflections on higher education, science, politics, economics and society. Following Dworkin (1977), we define 'moral position' as a combination of reason and belief. Fundamentally, a moral position is normative in nature: a set of value-judgements which informs a sense of right and wrong in contexts where objective means of ascertaining accuracy or validity are absent (MacIntyre [1981] 2011, 8). As we will see, doctoral scientists professional intentions are consciously shaped by 'non-scientific' - political, economic, social, philosophical values. Evident also is a strong sense of control over these intended professional trajectories.

In what follows, we describe in detail the characteristics of each moral position; drawing exclusively from the interview data to bring these moral positions to life.

\section{Scientific purist}

Scientific purists, who accounted for ten per cent of doctoral scientists, were most ardently opposed to the 'corruptive influence' of the KBE. Purists idealised the university as an 'ivory tower'; believing that a demonstrated distance from political, economic and social influences was needed to conduct scientific research in an unbiased and legitimate way.

Purists' ambitions were informed by their normative vision of science and the university. All hoped to become academic researchers, and understood the $\mathrm{PhD}$ as an academic apprenticeship. As one third-year medical researcher explained:

I want a career in research... I don't want to work for a private corporation. I feel this is why I've done the PhD.

Meanwhile, a second year medical researcher defended her view that doctoral researchers are legitimate, if junior, members of the academic community.

Some of my friends are cynical. I've heard people saying that academic research is a pyramid scheme and that the $\mathrm{PhD}$ qualification is just cheap labour to get things done. It's not a view that I share.

Purists' understandings of the scientist derived principally from academic norms; nevertheless, their view of academic life is traditional rather than contemporary. Research performance was judged not in terms of political, economic or social impact as stipulated in current KBE policies, but instead in relation to long-established academic indicators: adhering to disciplinary norms; publishing; winning grants and peer recognition. Purists believed that success in these aspects would establish their 'scientific credibility' and their place in the next generation of academic scientists (Latour and Woolgar [1979] 1986, 187).

The purists' ethos is highly reminiscent of Merton's scientific norms ([1942] 1973). These students are committed to values internal and specific to the (academic) scientific community; 'disinterestedness' being the particular principle guiding their aversion towards the KBE. For purists, the scientist driven by profit-making ceased to be a member of the scientific community in any meaningful sense. As this second year biologist reasoned:

I just can't get past this economy word. I'm thinking it's some kind of financial benefit...I tend to more think about the individual people who benefit rather than the greater research.

Purists tend to work in the biological sciences, and are mostly female. However, the gendered nature of the STEM disciplines warrants caution in inferring causation (Donald 2011). Certainly, we observed that disciplinary culture influenced the purist outlook. One final year zoologist 
believed that her specialist knowledge and research skills would be of little interest to the political and corporate stakeholders of the KBE. Subsequently, she struggled to envisage herself conducting research outside the academy. Typically, purists progressed from undergraduate to $\mathrm{PhD}$ study without a break for employment.

\section{Social idealist}

Fifteen per cent of doctoral scientists held a 'social idealist' outlook. Like the purists, idealists tended to be female and working in the biological sciences. Idealists shared the anti-capitalist stance of the purists, but promoted an image of the university where scientific researchers work with external stakeholders to improve society and challenge inequity. A third year medical researcher explained the political ideals informing her approach to research and, she assumed, those of her colleagues.

To work in a research environment, you've got to be a bit of a Leftie. I think most of us are... And that's everyone, not just the PhD student. I think you'd find it difficult to work in that setting and have quite a 'corporate view' of things.

Social idealists were motivated by the notion that scientific research could improve society. A second year conservationist described how this ideal had informed earlier choices in her research career.

My undergraduate was in zoology, and most of it was in behavioral ecology. My primary interest was in behavioral ecology, but.. in my opinion, [it's] not quite as useful as conservation, so I went into that. I'm lucky that I work in conservation; I feel that it does have value.

For other idealists, a preference for socially-useful science arrived later in their research careers. One second-year medical researcher explained how a disappointing performance against academic measures of success - negative laboratory results, a poor relationship with peers and a supervisor and difficulty getting published - resulted in a shift to a social idealist outlook. Despite this reconsideration of academic values, KBE science continued to lack appeal. Describing it as 'offputting', this idealist explained:

[The government] assumes that $\mathrm{PhDs}$ are going to go and make patents or go into commercial things and suddenly generate loads of money, whereas people that are actually doing PhDs are doing it because they like doing science.

Most idealists hoped to become academics, but expressed a wider understanding of scientific value than the purists. Their raison d'être echoes Derek de Solla Price's account of 'little science' (1963), where scientific research is organised to address specific societal needs. Accompanying this was a willingness to work with non-academic partners; several idealists received funding towards their doctoral from charitable and third-sector organisations.

\section{Pragmatist}

Fifty per cent of doctoral scientists were described as 'pragmatists'. These students held the most flexible moral position; recognising both traditional academic values and those of the KBE. Within this position, it is possible to distinguish further 'weak' and 'strong' pragmatists; representing 20 and 30 per cent of doctoral scientists respectively.

Strong pragmatists judged academic and KBE careers to be of equal merit and prestige, and explored careers in both domains. Weak pragmatists, however, viewed academic careers as the superior route. Furthermore, weak and strong pragmatists differed in terms of career planning. Weak pragmatists tend to passively 'hope for the best', despite acknowledging the difficulties of 
securing an academic post. This third year biologist noted the merit of considering non-academic careers, but had done little research herself.

You can't, like... ten years ago, focus on something and hopefully you'll get that goal at the end. Now you've got to have sort of plan B, C, D and E to cover the whole gambit. But, the main focus is still to become a lecturer.

Strong pragmatists, however, were far less attached to the goal of becoming an academic and considerably more proactive in exploring other professional opportunities. This second year bioengineer shared his inclusive understanding of the value of the $\mathrm{PhD}$.

I used to think the $\mathrm{PhD}$ was preparing me for an academic career in science, I actually don't think that at all anymore. I think it's preparing me to be a researcher - someone who thinks scientifically, and works scientifically. The skills I have got will also enable me to go out into a new research environment and innovate there.

Significant here is the reference to shifting perceptions: 'I used to think'. Pragmatists, like the purists and idealists, begin the $\mathrm{PhD}$ intending to become an academic. Weak pragmatists hold onto this aspiration, whereas strong pragmatists re-evaluate their futures more comprehensively. Strong pragmatists 'prepare for the worst', and they do not expect to obtain an academic. The transition to strong pragmatism was, however, commonly portrayed in negative terms: a lonely and difficult experience; resulting from low self-confidence or disengagement, and not the intervention of a supervisor or support or advisory service. One final year mathematics student reflected that the $\mathrm{PhD}$ served as a test, to identify those individuals suited to an academic career.

Are you passionate enough about this, do you have this odd drive? Are you a broken person that will just stay in the department all the time, ignore your family? [The $\mathrm{PhD}$ is] freedom to stare into the abyss and face down your demons and work out if you are the kind of person that can do this or not. I've seen dear friends who have fallen by the wayside... and quite a lot of my friends are either on anti-depressants or they've quit.

Students from a range of STEM disciplines subscribed to pragmatism, which was also not an obviously gendered position. In contrast to the purists and social idealists, many pragmatists reported having undertaken full-time work in between undergraduate and postgraduate study.

\section{Third-order capitalist}

Third-order capitalism - the position assumed by twenty five per cent of doctoral scientists - fully endorses the KBE view of scientific research - that of Fuller's 'third-order' capitalism. These students tended to be male, conducting research in applied disciplines, and held considerable and varied work experience prior to undertaking the $\mathrm{PhD}$.

Third-order capitalists did not wish to become academics, and nor had they at the start of their doctorates. These students saw the doctorate as a credential to enhance their employability and earnings in the non-academic labour market. A second year computing student explained his transition in these terms.

I used to work for a bank, and [it was] very competitive...I felt I was under-qualified in my team because there were 15 of us and I'd say 9 people had a $\mathrm{PhD}$. None of those people were made redundant. I was made redundant. People pursue knowledge to strengthen their bids [for work]. 
This student went on to note how other colleagues facing redundancy employed similar strategies 'paying something like $\$ 60,000$ for a master's course in the US'. This 'purchasing' of a higher degree as a positional good is precisely the type of behaviour anticipated in the KBE.

Third-order capitalists expressed no interest in forging an academic career, and their regard for academia was low. They considered academic research to be abstract and irrelevant. This second-year engineer, who combined his $\mathrm{PhD}$ with a role in a microelectronics company, lamented the perceived disconnect between academic inquiry and the 'useful' research conducted by industry.

The fact that a $\mathrm{PhD}$ student spends a year finding a problem I find funny. I go into my company - there are problems every single day. But yet you have $\mathrm{PhD}$ students finding problems.

Third-order capitalists were disinterested in academic measures of success; instead espousing an epistemology which valued knowledge in terms of economic worth. One student considered the written thesis as an inconvenience - 'an administrative overhead'; while peer-review publications received particularly disparaging criticism from another.

[Academia is] selfish because all you get is your name in various forms of publications. That's all you get. You don't get the satisfaction of having done anything. You don't feel happy because haven't done anything. Nothing will come out of your work. People don't ask hard questions. They just publish what they can.

\section{Discussion}

Mapping the four moral positions

\section{[Figure 1 here]}

Figure 1. Mapping the four moral positions upon the landscape of science and higher education

Figure 1 outlines the main ideological differences between the four moral positions. Contrasting views on knowledge creation, the university, the role of the scientist and the value of science differentiate each position. Less prominent, however, are the shared characteristics of each moral position, to which we shall now turn our attention.

\section{Exploring the shared foundations of the moral positions}

Firstly, we suggest that each moral position equates to an aspired professional identity. Thus, doctoral scientists' identities, varied though they are, are each moral in part; an observation which corresponds with earlier work by Mary Henkel, who found moral values to central to contemporary academic identities $(2000,15)$. We welcome doctoral scientists' efforts to bring moral values into their professional lives. The KBE raises pertinent moral questions about transformations in academic life, and economic and social change more broadly. We therefore consider it positive that doctoral scientists evaluate the political and economic promises of the KBE and its implications for science and higher education, and orientate their scientific identity accordingly. Indeed, the historian of science Steven Shapin suggests that the rapidity and uncertainty of contemporary knowledge creation necessitate the inclusion of moral values into the scientific enterprise (Shapin 2008, 303).

Related to this, however, is another shared characteristic, which prompts our concern. We suggest that each moral position is founded upon a limited critical evaluation of the KBE and is hindered by poor contextual understanding of the landscape of contemporary science and higher 
education. For example, from each moral position it is evident that all doctoral scientists fail to apprehend the boundary-less potential of the KBE. Each moral position is clearly premised upon the assumption that modern divisions between the university, industry, economy, society and the political continue to exist. We consider this a fundamental misunderstanding of the rationale and characteristics of the KBE and KBE policies discussed earlier in this paper, which undermines the likely robustness of each moral position as a suitable professional modus operandi.

It is quite plausible that, with better information, doctoral scientists could assume completely different moral positions. Scientific purists, social idealists and weak pragmatists elevate the university for the same reason that third-order capitalists denigrate it - its perceived distance from political and economic imperatives. However, if we consider that KBE policies envisage a closer relationship between the university, state and industry; a typology of moral positions distinguishable by contrasting views on the ivory tower model of academia seems uniformed and outdated. Each moral position, articulated so confidently by its proponents, could quickly unravel should doctoral scientists be encouraged to re-consider such contextual misconceptions and become better informed about the plethora of post-doctoral career destinations.

\section{Implications for doctoral scientists}

While we welcome doctoral scientists' recognition that the KBE raises complex ethical questions for science and the university, we express concern that the unnecessarily narrow foundation of each moral position may lead doctoral scientists to limit their 'horizons for action' (Hodkinson and Sparkes 1997). In this paper, we have demonstrated how each moral position influences career planning: purists, idealists and weak pragmatists attach stigma to non-academic careers; while thirdorder capitalists reject university careers based upon an impression of the detached and esoteric academic. This is troubling - not just for KBE stakeholders seeking to encourage flexibility in the labour market and wide-ranging contributions to growth - but for doctoral scientists, who will likely preclude themselves from many potential professional opportunities.

While strong pragmatists are distinguished from their peers for possessing greater awareness of post-doctoral careers, their narratives suggest isolation, struggle and diminished self-confidence. We therefore identify a clear need for improved information and support structures for all doctoral scientists.

\section{Pedagogical implications}

Elsewhere, we proposed three reforms to the STEM doctorate - regular discussion groups, reflexive writing and non-academic work placements - to enable doctoral students to develop better informed professional identities (Hancock and Walsh 2014). The data presented in this paper further support our assertion that doctoral scientists need to command a greater understanding of the wider political, economic, social and cultural context in which they exist. While our chief concern is to ensure that doctoral scientists prepare for their professional futures with insight and confidence; they will consequently be better positioned to contribute to the newly broadened and increasingly complex landscape of science and higher education, as KBE stakeholders would hope.

\section{Conclusion}

In this paper, we have presented data from a study of doctoral scientists' awareness of, and attitudes toward, the KBE. Doctoral scientists are aware of the KBE, and aspects of it are considered to impact upon their daily lives at the university. Doctoral scientists are, however, shown to differ markedly in terms of whether they view the KBE to be a positive or negative development for science, the university and their professional futures.

Perhaps the most important finding, however, is that each moral position is plagued by a poor understanding of the contemporary political economy of science and higher education. Despite the intention of the Roberts' reforms to heighten doctoral scientists' capacity to apply their skills and knowledge across diverse contexts, the doctoral scientists in this study relay notably narrow views about acceptable future careers, tied to a specific moral vantage point. More positively, we 
note that despite these diverse moral positions and professional aspirations, no student regretted undertaking the doctorate.

We acknowledge that this study is limited to the STEM disciplines and a single institution and encourage further research to explore the political, social and economic values of doctoral students and, how these in turn shape early expectations and future intentions. Nevertheless, since many aspects of doctoral education are generic, we are confident that these findings will have resonance beyond this study's particular empirical base.

We conclude that doctoral scientists' moral positions must be both better informed and more flexibly disposed if they are to serve as robust pillars of guidance through their professional futures. If unchallenged, the poor contextual understanding common to each moral position will lead to restricted career planning and overlooked opportunities. This situation must be addressed. The stakes - for doctoral scientists and KBE stakeholders alike - are simply too high.

\section{Acknowledgement}

This paper is based on the doctoral thesis of Sally Hancock. Elaine Walsh, Gwyneth Hughes and Stephen Webster are thanked for their expert supervision; as are Steve Fuller and Felicity Mellor for examining the thesis. The research was funded by Imperial College Graduate School.

\section{References}

Barnacle, R. 2005. Research education ontologies: exploring doctoral becoming. Higher education research and development 24: 179-188.

Barnacle, R. and G. Dall'Alba. 2011. Research degrees as professional education? Studies in Higher Education. 36: 459-470.

Barnett, R. 2011. Being a University. Abingdon, Oxon: Routledge

Becker, G. 1993. Human Capital. London: University of Chicago Press.

Bell, D. 1973. The coming of Post-Industrial Society: A Venture in Social Forecasting. London: Heinemann Educational.

Browne, J. 2010. Securing a sustainable future for higher education: an independent review of higher education funding and student finance. London: Department for Business, Innovation and Skills.

Callender, C. 2010. The Comprehensive Spending Review and Higher Education.

http://publicuniversity.org.uk/wp-content/uploads/2010/11/Callender.pdf. Accessed 27th June 2014.

Coates, H. 2006. Student engagement in campus-based and online education: university connections. London: Taylor \& Francis.

Cohen, L., L. Manion, and K. Morrisson. 2011. Research Methods in Education. Abingdon, Oxon: Routledge.

Castells, M. 1996. The rise of the network society. Cambridge, MA: Blackwell.

Confederation of British Industry. 2011. Building for Growth. London: Confederation of British Industry.

Collini, S. 2012. What are universities for? London: Penguin.

Council for Industry and Higher Education (CIHE). 2010. Talent Fishing: What Businesses Want from Postgraduates. London: CIHE.

De Solla Price, D. 1963. Little Science, Big Science. New York: Colombia University Press.

Donald, A. 2011. Where is Physics Barbie? Times Higher Education.

http://www.timeshighereducation.co.uk/story.asp?storycode=417235. Accessed 12th July 2014.

Dillman, D. A., J. D. Smyth and L. M. Christian. 2009. Internet, mail and mixed-mode surveys: the tailored design method. Hoboken, NJ: John Wiley \& Sons.

Driver, S. and Martell, L. 1992. New Labour: Culture and Economy.

http://www.sussex.ac.uk/Users/ssfa2/cultureandeconomy.pdf. Accessed 12th July 2014.

Dworkin, R. 1977. The Concept of a Moral Position.

http://www2.econ.iastate.edu/classes/econ362/Hallam/documents/ConceptofaMoralPosition.pdf (accessed 12th July 2014) 
Dyson, J. 2010. Ingenious Britain: Making the UK the leading high tech exporter in Europe. London: The Conservative Party.

Etzkowitz, H. 1983. Entrepreneurial Scientists and Entrepreneurial Universities in American Academic Science. Minerva 21: 198-233.

Etzkowitz, H. and Leydesdorff, L. A. 2001. Universities and the Global Knowledge Economy: a Triple Helix of University-Industry-Government Relations. London: Pinter.

European Commission. 2004. European Economy: 6. Luxembourg: Directorate for Economic and Financial Affairs.Fuller, S. 2003. Can Universities Solve the Problem of Knowledge in Society without succumbing to the Knowledge Society? Policy Futures in Education 1: 106-124. Gibbons M., H. Nowotny, S. Schwartzman, P. Scott and M. Trow. 1994. The New Production of Knowledge: The Dynamics of Science and Research in Contemporary Societies. London: SAGE. Gilbert, R. 2004. A framework for evaluating the doctoral curriculum. Assessment \& Evaluation in Higher Education 29: 299-309.

Hancock, S and E. Walsh. 2014. Beyond knowledge and skills: rethinking the development of professional identity during the STEM doctorate. Studies in Higher Education.

http://www.tandfonline.com/doi/abs/10.1080/03075079.2014.915301. Accessed 12th July 2014. Henkel, M. 2000. Academic identities and policy change in higher education. London: Jessica Kingsley.

HM Treasury. 2002. Investing in Innovation. London: HM Treasury.

HM treasury. 2004. Science \& innovation investment framework 2004 - 2014. London: HM Treasury.

HM Treasury. 2010. Spending Review 2010. London: HM Treasury.

HM Treasury \& Department for Business, Innovation and Skills. 2011. The Plan for Growth. https:/www.gov.uk/government/uploads/system/uploads/attachment_data/file/221514/2011budget growth.pdf. Accessed 12th July 2014.

Hodge, A. 2010. Review of progress in implementing the recommendations of Sir Gareth Roberts, regarding employability and career development of PhD students and research staff.

http://www.rcuk.ac.uk/documents/researchcareers/RobertReport2011.pdf. Accessed 12th July 2014. Labour Party. 2001. Ambitions for Britain: Labour's Manifesto 2001. Labour Party.

http://www.pixunlimited.co.uk/pdf/news/election/labourmanifesto1.pdf. Accessed 12th July 2014. Lambert, R. 2003. Lambert Review of Business-University Collaboration. London: HM Treasury. Latour, B. and S. Woolgar, [1979] 1986. Laboratory life: the social construction of scientific facts. London: SAGE.

Lauder, H., M. Young, H. Daniels, M. Balarin and J. Lowe 2012. Educating for the knowledge economy? Abingdon: Routledge.

Lawton-Smith, H. 2011. Entrepreneurship and 'regional' policy in London: a view from Birkbeck. Presented at the ESRC New Institutional Imperatives Seminar, 18th February 2011. University of Bristol, UK.

MacIntyre, A. [1981] 2011. After Virtue. London: Bloomsbury.

Malchup, F. 1962. The Production and Distribution of knowledge in the United States. Oxford:

Princeton University Press.

Marginson, S. 2007. Prospects of Higher Education. Rotterdam: Sense.

Mason, M., M. Goulden and K. Frasch 2009. Why graduate students reject the fast track. https://www.law.berkeley.edu/files/Grad Students Fast Track_Article.mamason.pdf. Accessed 11 th July 2014.

McAlpine, L and E. Emmioglu. 2014. Navigating careers: perceptions of sciences doctoral students, post-PhD researchers and pre-tenure academics. Studies in Higher Education. http://www.tandfonline.com/doi/abs/10.1080/03075079.2014.914908? src=recsys. Accessed 12th July 2014.

Merton, R. K. [1942] 1973. The Sociology of Science: Theoretical and empirical investigations. Chicago: University of Chicago Press. 
Nowotny, H., P. Scott and M. Gibbons. 2002. Re-thinking science: knowledge and the public in an age of uncertainty. Cambridge: Polity Press.

Nyquist, J. 2002. The PhD - a tapestry of change for the 21st century. Change Nov/Dec: 12-20.

OECD. 2001. Devolution and globalisation. Paris: OECD.

Park, C. 2005. New Variant PhD: The changing nature of the doctorate in the UK. Journal of

Higher Education Policy and Management 27 (2): 189-207.

Park, C. 2007. Redefining The Doctorate. York: Higher Education Authority.

Peters, M. A. 2009. 'Education and the knowledge economy'. In Creativity and the Global

Knowledge Economy, edited by Peters, M., S. Marginson and P. Murphy, 51-70. New York: Peter

Lang.

Powell, S., and H. Green. 2007. The Doctorate Worldwide. Berkshire: Open University

Press/Society for Research into Higher Education.

Roberts, G. 2002. SET for success: The supply of people with science, technology, engineering and mathematics skills. London: HM Treasury.

Lord Sainsbury of Turville. 2007. The Race to the Top: a Review of the Government's Science and Innovation Programmes. London: HM Treasury.

Sauermann, H and M. Roach, M. 2012. Science PhD Career Preferences: Levels, Changes, and

Advisor Encouragement. PLOS ONE.

http://www.plosone.org/article/info\%3Adoi\%2F10.1371\%2Fjournal.pone.0036307. Accessed 12th July 2014.

Science is Vital. 2011. Careering Out of Control: A Crisis in the UK Science Profession? http://scienceisvital.org.uk/wp-content/uploads/2013/01/ScienceCareers-report-WEB.pdf. Accessed 25th August 2014.

Select Committee on Science and Technology. 2012. Higher Education in Science, Technology, Engineering and Mathematics subjects. London: The Stationery Office.

Shapin, S. 2008. The Scientific Life. London: University of Chicago Press.

Sid Nair, C., P. Adams and P. Mertova. 2008. Student Engagement: The Key to Improving Survey

Response Rates. Quality in Higher Education 14: 225-232.

Slaughter, S. and L. Leslie 1997. Academic Capitalism. Baltimore: Johns Hopkins University Press.

Slaughter, S. and G. Rhodes. 2004. Academic capitalism and the new economy: markets, state, and higher education. Baltimore: Johns Hopkins University Press.

Stehr, N. 1994. Knowledge societies. London: SAGE.

Strauss, A. and J. Corbin. 1998. Basics of Qualitative Research. Thousand Oaks: SAGE.

Temple, P. (Ed.) 2011. Universities in the Knowledge Economy. London: Routledge.

Vitae. 2011. What do researchers do? Vitae. https://www.vitae.ac.uk/vitae-

publications/reports/what-do-researchers-do-career-paths-vitae-2011.pdf. Accessed 12th July 2014.

Vitae. 2013. What do researchers do? https://www.vitae.ac.uk/vitae-publications/reports/what-doresearchers-do-early-career-progression-2013.pdf. Accessed 12th July 2014.

Walsh, E., and K. Anders, S. Hancock, and L. Elvidge. 2011. Reclaiming creativity in the era of impact: exploring ideas about creative research in science and engineering. Studies in Higher Education http://dx.doi.org/10.1080/03075079.2011.620091. Accessed 12th July 2014.

Warhurst, C. 2008. The Knowledge Economy, skills and government labour market intervention. Policy Studies 29 : 71-86.

Wolf, A. 2004. Education and Economic Performance: Simplistic Theories and Their Policy

Consequences. Oxford Review of Economic Policy 20: 315-333.

World Bank. 2002. Building knowledge economies: opportunities and challenges for EU accession countries. Paris: World Bank. 